\title{
KENDALA-KENDALA YANG DIHADAPI SISWA MENENGAH ATAS (SMA) SELAMA MELAKUKAN PROSES PEMBELAJARAN BERBASIS ONLINE (DARING)SAAT PANDEMI COVID-19 DI KABUPATEN TANAH DATAR
}

\section{THE OBSTACLES FACED BY HIGH SCHOOL STUDENTS DURING THE ONLINE-BASED LEARNING PROCESS DURING THE COVID-19 PANDEMIC IN TANAH DATAR DISTRICT}

\author{
Widiana $^{1}$, Yolivia Irna Aviani ${ }^{2}$ \\ Jurusan Psikologi, Universitas Negeri Padang \\ winawidiana42574@gmail.com
}

\begin{abstract}
Pandemic Covid-19 makes students have to do the learning process online. This study aims to find out what problems students feel during the online learning process so that students feel anxious and depressed. This study used qualitative method with a sample number of 47(male= 9, female= 38) Senior High School students as many as 39, Vocational High School students as many as 2, and Islamic Senior High School Students as many as 6in Tanah Datar-District. The sampling data of this study used Google Form that contain question to surveys about online learning and open question are structured to identify the causing problems are experianced on students anxiety in online learning and how to overcome that. The result of this study showed the factors are causing on student anxiety during online learning. That factors are following difficulty on internet network in online learning and student do not understand with material presented by teachers.
\end{abstract}

Keywords: Anxiety, factors of anxiety, online learning, pandemic period, students

\section{ABSTRAK}

Pandemi Covid-19 membuat siswa harus melakukan proses pembelajaran secara online. Penelitian ini bertujuanuntuk mengetahuimasalahyang dialami oleh siswa saat melakukan proses belajar secara online (daring) sehingga siswa merasa cemas dan tertekan. Penelitian ini menggunakan metode kualitatif dengan melibatkan 47 (lakilaki $=9$, perempuan $=38$ ) responden yang merupakan siswa SMA sebanyak 39, SMK sebanyak 2, dan MA sebanyak 6 responden di Kabupaten Tanah Datar. Pengambilan data menggunakan Google Form yang berisi pertanyaan berupa survey tentang pembelajaran daring dan pertanyaan terbuka tentang pertanyaan yang disusun untuk mengetahui permasalahan apa saja yang dialami ketika melakukan pembelajaran daring yang memicu munculnya kecemasan beserta cara mengatasi permasalahan tersebut. Hasil yang ditemukan adalah terdapat beberapa faktor yang menjadi pemicu munculnya kecemasan siswa selama melakukan pembelajaran daring. Faktor tersebut yaitu susahnya jaringan internet dan kesulitan memahami materi yang diberikan oleh guru.

Kata Kunci:Masa pandemic, faktor kecemasan, kecemasan, pembelajaran daring, siswa 


\section{PENDAHULUAN}

Covid-19 merupakan suatu wabah yang melanda Indonesia sejak 2 maret 2020. Wabah ini adalah sebuah virus yang dapat menularkan penyakit pada saluran pernapasan manusia. Akibatnya beberapa sector di Indonesia mengalami perubahan salah satunya sisitem pendidikan. Pemerintah melakukan segala upaya untuk mengurangi angka penyebaran virus Covid-19, salah satunya yaitu merubah sistem pembelajaran yang dulunya belajar disekolah menjadi belajar dirumah dengan system online/daring. Sesuai dengan surat yang diedarkan oleh Kementrian Pendidikan dan Kebudayaan tahun 2020 nomor 4 perubahan sistem ini sudah mulai diberlakukan sejak bulan maret 2020 .

Pembelajaran daring ialah aktivitas yang dapat membantu mahasiswa dan dosen bertemu via online (Kuntarto, 2017) dengan menggunakan perangkat mobile seperti android, laptop dan computer bisa digunakan sebagai alat untuk membantu lancarnya proses belajar online dan juga bisa untuk mengakses informasi yang ada di jaringan internet (Gikas \& Grant, 2013). Media yang dapat digunakan untuk mengakses pembelajaran daring beragam, bisa menggunakan kelas-kelas virtual yang biasa dikenal dengan Google Classroom dan bisa juga menggunakan aplikasi pesan singkat seperti whatsapp dan juga bisa menggunakan sosial media seperti facebook dan instagram (Enriquez, 2014; Iftakhar, 2016; Kumar \& Nanda, 2019; So, 2016).

Pembelajaran dengan sistem daring memiliki beberapa kelebihan dan kekurangan dalam pelaksanaannya. Kelebihannya adalah kegiatan belajar mengajar ini dapat membantu siswa untuk mengakses informasi yang lebih luas sehingga proses belajar daring menjadi lebih mudah.Kekurangan dalam pembelajaran daring adalah munculnya beberapa kendala dalam proses penerapannya. Kendala awal dalam proses pembelajaran daring adalah jaringan internet yang tidak memadai di beberapa daerah(Hastini, Fahmi, \& Lukito, 2020). Selain itu penggunaan jaringan internet yang melebihi batas kuota penggunaan dapat memunculkan masalah baru bagi siswa yang memiliki financial di bawah rata-rata (Morgan, 2020).

Penerapan kebijakan pembelajaran daring ini memunculkan masalah baru bagi siswa, salah satunya siswa merasa cemas atau tertekan. Salah satu penyebab siswa merasa tertekan adalah siswa merasa kebingungan karena mereka tidak mengerti akan penjelasan materi yang dijelaskan oleh guru dan batas waktu pengumpulan tugasnya 
jugarelative singkat serta tugas yang diberikan oleh guru lebih banyak dibandingkan ketika sekolah seperti biasa(Chaterine, 2020; Raharjo, Dwi Bowo \& Sari, 2020)

Dacey (2000) mengatakan bahwa kecemasan adalah suatu keadaan yang diikuti dengan ketakutan atau kekhawatiran terhadap sesuatu yang belum jelas kapan terjadinya. Gail W Stuart membagi kecemasan kedalam 3 respon, yaitu respon perilaku adalah respon yang ditandainya dengan munculnya perasaan gelisah, berbicara menjadi lebih cepat dan adanya reaksi terkejut yang berlebihan. Respon kedua yaitu respon kognitif dimana respon ini ditandai dengan menjadi pelupa terhadap suatu hal dan kurang berkonsentrasi terhadap suatu masalah. Respon yang ketiga yaitu ditandai dengan adanya sikap yang miudah terganggu dan menjadi tidak sabar (Annisa \& Ifdil, 2016)

Penelitian ini akan difokuskan pada siswa Menengah Atas (SMA) untuk mengetahui masalah apa saja yang dialami selama melakukan belajar online (daring) karena mereka dinilai memiliki tanggung jawab yang besar terhadap masa depannya, yaitu memasuki dunia kerja dan melanjutkan jenjang pendidikan di perkuliahan. Hasil dari penelitianini diharapkan dapat melihat gambaran mengenai permasalahan apa saja yang dialami oleh siswa selama melakukan pembelajaran daring dan dapat menjadi bahan evaluasi untuk pemerintah dalam menerapkan sistem pembelajaran yang nyaman untuk siswa.

\section{METODE PENELITIAN}

Metode yang digunakan dalam penelitian ini ialah metode kualitatif dengan jumlah responden sebanyak 47responden (laki-laki $=9$, perempuan= 38) yang merupakan siswaSMA sebanyak 39, SMK sebanyak 2, dan MA sebanyak 6 responden di Kabupaten Tanah Datar. Pengambilan data menggunakan Google Form yang berisi pertanyaan berupa survey tentang pembelajaran daring dan permasalahan apa saja yang dialami ketika melakukan pembelajaran daring yang memicu munculnya rasa cemas beserta cara mengatasi permasalahan tersebut. Penyebaran data dilakukan dengan menggunakan media sosial yaitu Whatsapp. Data yang diperoleh dari responden kemudian dianalisis, adapun tahapan dalam menganalisa jawaban dari partisipan yaitu dengan mencoding jawaban dari partisipan terlebih dahulu lalu menganalisa jawaban tersebut kemudian dikelompokkan berdasarkan tema-tema yang telah ditentukan. 


\section{HASIL PENELITIAN}

Hasil dari analisis data didapatkan bahwa25 responden menggunakan hp, laptop, buku, modul, dan LKS sebagai media yang digunakan untuk melakukan proses pembelajaran daring, sedangkan 22 responden hanya menggunakan hp saja dalam melakukan proses pembelajaran daring. Hasil analisis dapat dilihat pada tabel 1 sampai dengan tabel 4 dibawah ini:

Tabel 1. Kendala selama melakukan proses pembelajaran daring $(n=47)$

\begin{tabular}{lc}
\hline Kendala selama melakukan proses pembelajaran dari & Frekuensi \\
\hline Jaringan dan kuota internet & 26 \\
\hline Kesulitan dalam memahami materi dan mencari jawaban tugas & 12 \\
\hline Membantu orang tua bekerja & 2 \\
\hline Tugas yang masuk secara tiba-tiba & 1 \\
\hline Mata menjadi sakit & 1 \\
\hline Tidak ada kendala & 2 \\
\hline Dan lain-lain & 3 \\
\hline
\end{tabular}

Tabel 2. Hal yang dirasakan selama melakukan pembelajaran daring $(n=47)$

Hal yang dirasakan selama melakukan pembelajaran daring $\quad$ Frekuensi

Merasa kesal dan cemas ketika tidak memahami materi 25

$\begin{array}{ll}\text { Merasa sedih ketika nilai turun selama melakukan pembelajaran } & 17\end{array}$

daring

Merasa cemas dan takut ketika tidak mengerjakan tugas dengan $\quad 24$

tepat waktu

Tabel 3. Cara mengatasi kendala selama melakukan pembelajaran daring $(n=47)$

Cara mengatasi kendala selama melakukan pembelajaran daring Frekuensi

Berusaha mengikuti pembelajaran daring dengan maksimal $\quad 5$

Meminta bantuan orang tua dan membantu orang tua terlebih 2 dahulu

\begin{tabular}{lc}
\hline Membagi waktu antara kerja dan belajar & 3 \\
\hline Mencari tempat yang memiliki sinyal yang bagus & 18 \\
\hline Mencari informasi melalui guru, teman dan google & 42 \\
\hline Tidak melakukan apapun & 4 \\
\hline Dll & 5 \\
\hline
\end{tabular}

Tabel 4. Bentuk kecemasan yang dirasakan selama melakukan pembelajaran daring ( $n=47)$

Bentuk kecemasan yang dirasakan selama melakukan pembelajaran Frekuens daring i

Merasa pusing jika tidak bisa mengatasi kendala yang dirasakan 31

Jantung berdetak kencang ketika terlambat mengikuti kegiatan

33

belajar daring 
Dari tabel 1 dapat dilihat kendala apa saja yang dirasakan oleh siswa selama melakukan proses pembelajaran daring, di tabel 2 dapat dilihat hal apa saja yang mereka rasakan selama melakukan pembelajaran daring, di tabel 3 dapat dilihat hal apa saja yang mereka lakukan untuk mengatasi kendala tersebut dan tabel 4 menunjukkan bentuk kecemasan yang mereka rasakan selama melakukan pembelajaran daring.

Berdasarkan tabel 1 ditemukan enam kendala selama melakukan pembelajaran daring. Kendala yang paling berpengaruh yang dirasakan oleh siswa adalah susahnya jaringan internet dan tidak memiliki kuota internet $(n=26)$. Karena susahnya jaringan internet membuat siswa sulit untuk mengirim tugas dan mendengarkan materi pembahasan yang sedang berlangsung secara onlineyang menyebabkan pembelajaran online yang diikuti oleh siswa menjadi tidak lancar (Morgan, 2020). Tidak hanya itu siswa yang memiliki financial dibawah rata-rata juga mengalami kesulitan untuk membeli kuota internet yang menyebabkan mereka tidak bisa mengikuti kegiatan belajar online ketika kuota internet tidak ada (Naserly, 2020)

Hal ini akan menyebabkan siswa merasa kesal karena mereka tidak memahami materi yang dijelaskan oleh guru selama proses belajar online sedang berlangsung. Selain itu mereka juga cemas dan takut jika mereka tidak menyelesaikan tugas dengan tepat waktu yang juga berpotensi mengakibatkan turunnya nilai prestasi yang menyebabkan siswa merasa sedih apabila nilai mereka turun selama melakukan proses pembelajaran daring (tabel 2).

Adapun upaya yang dilakukan siswa untuk mengatasi kendala yang mereka rasakan (tabel 3) tadi yaitu dengan mencari informasi mengenai tugas dan materi kepada guru, teman dan juga google $(n=42)$. Pembelajaran daring akan semakin lebih efektif apabila masih adanya komunikasi antara guru dan murid(Kaufmann \& Vallade, 2020). Selain itu pembelajaran daring akan lebih menyenangkan apabila adanya respon positif dari guru(Pakpahan \& Fitriani, 2020). Selain itu bagi siswa yang kesulitan dalam jaringan internet mereka berusaha untuk mencari tempat dengan kapasitas sinyal yang bagus $(n=18)$ agar mereka tetap dapat mengikuti pembelajaran daring dengan maksimal.

Adapun dalam menjalani proses pembelajaran daring ini, mucul bentuk-bentuk kecemasan (tabel 4) yang mulai dirasakan oleh siswa. Siswa merasakan pusing apabila 
mereka tidak bisa mengatasi masalah yang dihadapi selama proses pembelajaran daring $(\mathrm{n}=31)$. Selain itu mereka juga merasakan detak jantung mereka yang berdetak kencang apabila mereka terlambat dalam mengikuti proses belajar daring, karena mereka takut ketinggalan informasi yang menyebabkan mereka tidak memahami materi yang diberikan pada hari itu. Karena tugas yang diberikan selama belajar daring rutin, siswa mulai merasakan pola tidur mereka yang mulai terganggu karena tugas yang tidak hentinya diberikan oleh guru.

\section{DISKUSI}

Pembelajaran daring merupakan aktivitas yang dapat membantu mahasiswa dan dosen bertemu via online (Kuntarto, 2017) dengan menggunakan perangkat mobile seperti android, laptop dan computer bisa digunakan sebagai alat untuk membantu lancarnya proses belajar online dan juga bisa untuk mengakses informasi yang ada di jaringan internet (Gikas \& Grant, 2013). Media yang dapat digunakan untuk mengakses pembelajaran daring beragam, bisa menggunakan kelas-kelas virtual yang biasa dikenal dengan Google Classroom dan bisa juga menggunakan aplikasi pesan singkat seperti whatsapp dan juga bisa menggunakan sosial media seperti facebook dan instagram (Enriquez, 2014; Iftakhar, 2016; Kumar \& Nanda, 2019; So, 2016). Kecemasan adalah suatu keadaan yang diikuti dengan ketakutan atau kekhawatiran terhadap sesuatu yang belum jelas kapan terjadinya (Dacey, 2000).

Selama proses pembelajaran daring sebagian siswa merasakan tekanan atau kecemasan dikarenakan adanya perasaan bosan setelah dua minggu melaksanakan pembelajaran daring, kecemasan mulai dirasakan pada siswa yang orangtuanya memiliki penghasilan yang rendah dan munculnya gangguan emosi yang disebabkan oleh banyaknya tugas (Irawan, Dwisona, \& Lestari, 2020). Munculnya masalah psikologis yang dialami oleh mahasiswa selama melakukan pembelajaran online di masa pandemic Covid-19 ditemukan bahwa kendala selama melakukan pembelajaran selama daring ini yaitu sulitnya berkonsentrasi dan memahami materi yang diberikan. Tidak hanya itu ditemukan 79 mahasiswa yang mengalami kecemasan ringan (41,58\%), 32 mahasiswa mengalami kecemasan sedang $(16,84 \%)$ selama melakukan proses belajar online (Hasanah, Immawati, \& Livana, 2020).

\section{KESIMPULAN DAN SARAN}


Sistem pembelajaran secara online yang dilakukan selama masa pandemic Covid19 ini menimbulkan perasaan cemas yang dirasakan oleh beberapa siswa di Kabupaten Tanah Datar. Hal ini disebabkan karena sulitnya jaringan internet dan ketidak mampuan dalam membeli paket data. Selain itu kesulitan dalam memahami materi yang mengakibatkan siswa kesulitan dalam mengerjakan tugas. Namun siswa melakukan beberapa upaya untuk mengatasi kesulitan yang mereka hadapi seperti mereka akan mencari informasi kepada guru, teman dan google dan mereka juga berusaha semaksimal mungkin mencari sinyal agar dapat mengikuti proses pembelajaran daring.

Penelitian ini nantinya diharapkan bisa menjadi sebuah referensi baru yang dapat diterapkan selama proses pembelajaran daring yang menyenangkan untuk siswa sehingga siswa dapat mengikutinya secara optimal dan dapat dijangkau oleh siswa di beberapa daerah dan kalangan. Diharapkan kedepannya dilakukan penelitian yang dapat menggali lebih dalam tentang gambarankecemasan yang dirasakan oleh siswa selama melakukan proses pembelajaran daring dan mencari tahu strategi yang cocok untuk mengatasi masalah yang ada pada siswa selama melakukan pembelajaran daring.

\section{DAFTAR PUSTAKA}

Annisa, D. F., \& Ifdil, I. (2016). Konsep kecemasan (anxiety) pada lanjut usia (lansia). Konselor, 5(2), 93. https://doi.org/10.24036/02016526480-0-00.

Chaterine, R, N. (2020). Siswa belajardari rumah, KPAI: Anak-anak stress dikasih tugas banyak. Retrieved Desember 20, 2020 from: https://news.detik.com/berita/d4944071/siswa-belajar-dari-rumah-kpai-anak-anak-stres-dikasih-banyak-tugas.

Dacey, J.S. (2000). Your anxious child: How parents and teachers can relieve anxiety in children. San Fransisco: Jossey-Bass Publisher.

Enriquez, M. A. S. (2014). Students ' perceptions on the effectiveness of the use of edmodo as a supplementary tool for learning. DLSU Research Congress, 6-11. https://doi.org/10.1017/CB09781107415324.004

Gikas, J., \& Grant, M. M. (2013). Mobile computing devices in higher education: Student perspectives on learning with cellphones, smartphones \& social media. Internet and Higher Education, 19, 18-26. https://doi.org/10.1016/j.iheduc.2013.06.002.

Hasanah, U., Ludiana, Immawati, \& PH, L. (2020). Gambaran psikologis mahasiswa dalam proses pembelajaran selama pandemi Covid-19. Jurnal Keperawatan Jiwa, 8(3), 299-306. https://jurnal.unimus.ac.id/index.php/JKJ/article/view/5941.

Hastini, L. Y., Fahmi, R., \& Lukito, H. (2020). Apakah pembelajaran menggunakan teknologi dapat meningkatkan literasi manusia pada generasi $\mathrm{z}$ di indonesia? Jurnal Manajemen Informatika (JAMIKA), 10(1), 12-28. https://doi.org/10.34010/jamika.v10i1.2678.

Iftakhar, S. (2016). Google classroom: what works and how? Journal of Education and Social Sciences, 3, 12-18.

Irawan, A.W., Dwisona., Lestari, M. (2020). Psychological impacts of students on online 
learning during the pandemic covid-19. KONSELI : Jurnal Bimbingan dan Konseling, 7(1), 53-60, https://doi.org/10.24042/kons.v7i1.6389.

Kaufmann, R., \& Vallade, J. I. (2020). Exploring connections in the online learning environment: student perceptions of rapport, climate, and loneliness. Interactive Learning Environments, $O(0), \quad 1-15$. https://doi.org/10.1080/10494820.2020.1749670.

Kumar, V., \& Nanda, P. (2019). Social media in higher education: A framework for continuous engagement. International Journal of Information and Communication Technology Education, 15(1), 109-120. https://doi.org/10.4018/IJICTE.2019010108.

Kuntarto, E. (2017). Keefektifan model pembelajaran daring dalam perkuliahan bahasa indonesia di perguruan tinggi. Journal Indonesian Language Education and Literature, 3(1), 53-65.

Morgan, H. (2020). Best practices for implementing remote learning during a pandemic. The Clearing House: A Journal of Educational Strategies, Issues and Ideas, 93(3), 135-141. https://doi.org/10.1080/00098655.2020.1751480.

Naserly, M. K. (2020). Implementasi zoom, google classroom, dan whatsapp group dalam mendukung pembelajaran daring (online) pada mata kuliah bahasa inggris lanjut. Journal of Chemical Information and Modeling, 4(2), 155-165.

Pakpahan, R., \& Fitriani, Y. (2020). Analisa pemanfaatan teknologi informasi dalam pembelajaran jarak jauh di tengah pandemi virus corona covid-19. JISAMAR (Journal of Information System, Applied, Management, Accounting and Research), $4(2), 30-36$.

Raharjo, D, B \& Sari, R. R. N. (2020). . Belajar online di tengah corona, ada siswa mengeluh tensi darah naik. Retrieved Desember 18, 2020 from: https://www.suara.com/news/2020/03/19/205940/belajar-online-di-tengahcorona-ada-siswa-mengeluh-tensi-darah-naik?.

So, S. (2016). Mobile instant messaging support for teaching and learning in higher education. Internet and Higher Education, 31, 32-42. https://doi.org/10.1016/j.iheduc.2016.06.001. 